
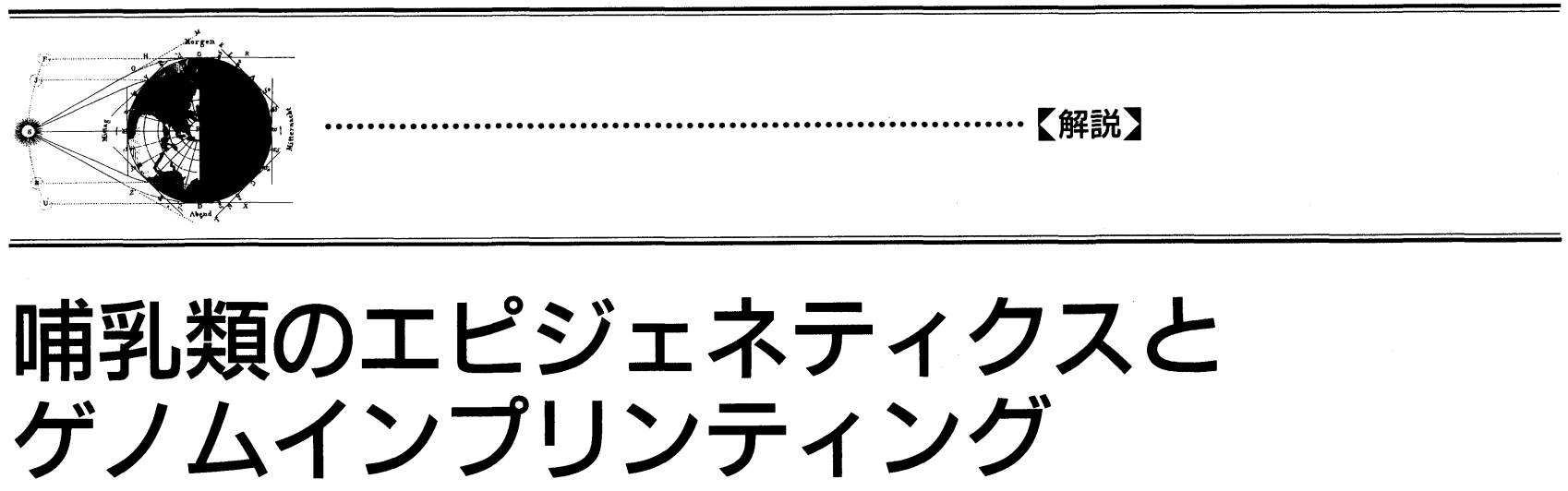

\title{
幸田 尚，石野史敏
}

最近，核移植による哺乳類の体細胞クローン作製が大きな話 題となっている. 1980 年代に, やはり核移植の技術によって 見いだされたゲノムインプリンティングという現象と，クロ ーン動物で明らかになった個体発生における遺伝子の発現カ スケードの可逆性を, エピジェネティクスという視点から統 一的に見直すことにより，哺乳類のゲノムの新たな特徵が浮 かび上がってくる.

我々哺乳類は，父親と母親からそれぞれ 1 対の遺伝子 のセットを受け継ぐが，これはDNA のレベルでみれ ば，どちらも等価であると考えられる．しかし，機能的 にはこれらを完全には同じものとして扱うことができな い事実が古くから知られている，たとえば，ウマとロバ の種間雑種であるラバ (mule) は，父親をロバ，母親を ウマとして生まれた雑種のことで，ロバとウマのどちら でもない，いわゆる「合いの子」であるが，この父親と 母親を逆にして生まれた動物はケッテイ (hinny) と呼ば れ，外見も性質もラバとはまた違った動物になるゲ゙ノ ムの DNA だけを考えれば，この 2 つの動物は同じ遺伝

Genomic Imprinting and Epigenetic Regulation of Genome in Mammals

Takashi KOHDA, Fumitoshi ISHINO, 東京工業大学遺伝子実験 施設
子セットをもつわけで，同じ動物が生まれてもよさそう なものであるが，ロバのゲノム，ウマのゲノムが父親か ら伝わったか母親から伝わったかで, 生まれる動物自体 が違ってしまう.

このように，ゲノムが父親由来か母親由来かで機能的 差異を示す現象は，1980 年代になって，核移植によっ て父親由来のゲノムあるいは母親由来のゲノムのみを 2 セットずつもつ単為発生胚を人工的に作製する実験 ${ }^{(1,2)}$ や，染色体の一部を片親性二倍体としてもつマウスを体 系的に作る遺伝学的実験 ${ }^{(3)}$ からはっきりと証明され, ゲ ノムインプリンティングと名づけられた。つまり，ゲノ ム DNA の一次配列の他に, 何かそれぞれの親に由来す る情報が「刷り込まれている」ということである。この ようなゲノムDNA に刷り込まれた情報は個体発生を通 じて体細胞では維持されるが，次の世代を作る生殖細胞 系列の中では一度消去され，その後再び精子あるいは卵 が作られるときに，それぞれの親の性に従って再び刷り 込みが起こると考えられる(図 1). その後, 哺乳類の遺 伝子には体細胞において 2 つの対立遺伝子 (allele) のう ち，父親に由来した一方の allele のみが発現するもの (paternally expressed genes, Pegs)，あるいは母親に 由来したもののみが発現するもの（maternally expres- 


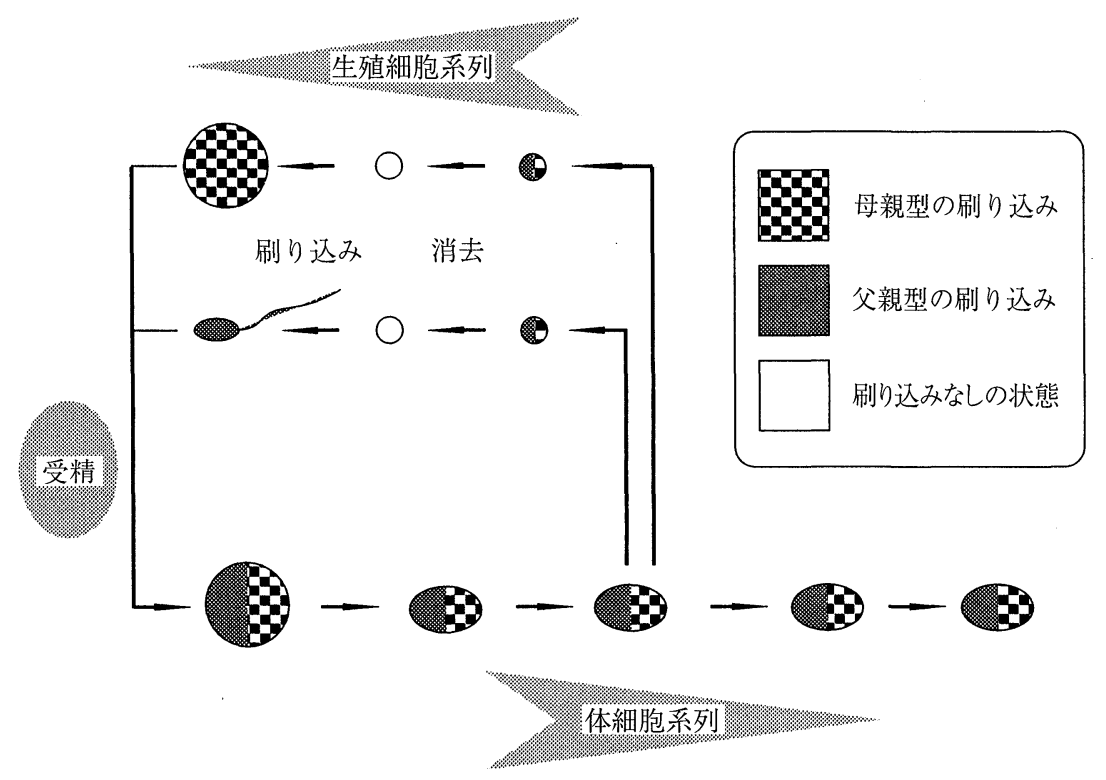

図 1 -哺乳類のライフサイクルとインプリンティング

哺乳類のライフサイクルでは, そのほとんどでインプリンティングの状態が維持されている. しかし, 次の世代に染色体が受け継がれると, その染色体が親の世代でどちらの親の性を記憶していたかにかかわらず，それぞれの対立遺伝子は父親由来のものと母親由来のものとして ふるまうことから, 生殖細胞系列では一度インプリンティングの状態が「刷り込みなし」の状態に消去され, 改めて精子形成時には父親型 に, 卵形成時には母親型に刷り込みが行なわれると考えられる。このようなインプリンティングの書き換えは, 体細胞系列では起こらず, 生殖細胞系列でのみ起こる現象である。

sed genes, $\mathrm{Megs}$ )があることが示され，このような遺伝 子をインプリンティング遺伝子と呼ぶようになった。

\section{インプリンティング遺伝子と疾患}

インプリンティング遺伝子は, 両親から受け継いだ 2 つの allele のうち，父親，あるいは母親のいずれか一方 のみが発現する。そこで, これらの遺伝子が何らかの疾 患の原因遺伝子になっている場合, 通常の遺伝病とは異 なったいくつかの特徵的な性質がみられる.すなわち， 変異が父親から伝わったか母親から伝わったかによっ て，表現型の現われ方がまったく異なるのである．原因 となる遺伝子が Peg 遺伝子の場合は, 母親側の allele は そもそも発現していないので，変異が父親から伝われば 優性遺伝のような遺伝様式を示すのに対して，母親から 遺伝した場合は表現型がまったく現われないことにな る。逆にいえば，どちらか一方の親由来で表現型が現わ れる遺伝病の原因遺伝子は，インプリンティング遺伝子 である可能性が高いと考えられる。また，稀に配偶子形 成時の染色体不分離などが原因で, 染色体が 1 つ失わ れ，その失われた染色体のもう一方の親から由来した染 色体が 2 本となる染色体異常（片親性二倍体）が起こる ことがある。この場合，通常の遺伝子であれば正常な個
体と発現量に違いはないが, インプリンティング遺伝子 の場合は発現が失われてしまったり, 逆に正常個体に対 して 2 倍の発現量となることが予想される.したがっ て，片親性二倍体によってひき起こされる異常の多く は, インプリンティング遺伝子が原因となっていること が予想される.

このようなインプリンティング遺伝子が原因である遺 伝病としては, Prader-Willi 症候群 ${ }^{(4)}$, Angelman 症候 群 ${ }^{(4)}$, Beckwith-Wiedemann 症候群(5), Silver-Russell 症候群 ${ }^{(6)}$ などが知られている。これらは精神遅滞や発育 不全, 様々な形態異常, 癌の好発など, 1 つの出来事が 原因であっても種々の表現型を伴う。インプリンティン グ遺伝子は染色体上で近接して複数存在し, 共通のイン プリンティングの制御を受けている場合がしばしば認め られる. 片親性二倍体や，1つのインプリンティングド メインの調節領域の変異や転座などによって, 複数のイ ンプリンティング遺伝子の発現が同時に異常を来たし, 複数の表現型の異常がひき起こされるのも, インプリン ティング遺伝子が原因となる遺伝病の特徵といえるかも しれない.

インプリンティングを受けることが最初に報告された 遺伝子は, Igf2（インスリン様増殖因子 2) であった ${ }^{(7)}$. これはIgf2 遺伝子のノックアウトマウスを作製したと 
ころ，その表現型の遺伝のしかたが通常の遺伝子と異な っていたことから，偶然見つけられたものであった。 の後, 様々な方法でインプリンティング遺伝子を同定す る試みが行なわれ，現在では 50 以上が知られている. 筆者らは, マウスにおいて母親由来のゲノムを二倍体で もつ単為発生胚，あるいは父親由来のゲノムを二倍体で もつ雄性発生胚を人工的に作製し，これらと父親と母親 由来のゲノムをもつ通常の肧で発現している遺伝子を, サブトラクション法や DNA チップで解析することによ って, 体系的にインプリンティング遺伝子の同定を試み てきた ${ }^{(8 \sim 10)}$.そして,これまでに $P e g$ 遺伝子を $13, \mathrm{Meg}$ 遺伝子を 13 単離することに成功した。 これらの遺伝子に は, すでに機能が知られているもの以外に新規の遺伝子 も多く含まれていたが，これらの間で機能的な共通性を 見いだすことは難しい。

筆者らが同定した新規インプリンティング遺伝子の中 でも, Peg3 はいくつかの点で興味がもたれる. Peg3 は $\mathrm{C}_{2} \mathrm{H}_{2}$ 型のジンクフィンガータンパク質で, マウスの成 体ではニューロンやグリアなど神経系の細胞で比較的強 い発現が認められる(11). ノックアウトマウスを作製す ると, 体の大きさが小さくなるとともに, 雌の場合は出 産した後典型的にみられる, 授乳を含めた子育ての行動 に著しい障害が認められる。この遺伝子は, マウスでは 7 番染色体近位部，ヒトでは 19 番染色体の長腕に位置
しているが, この領域は，ヒトのグリオーマ(グリア細 胞から発生する悪性脳腫瘍)で共通して染色体の loss of heterozygosity (LOH) が高頻度で観察され, 複数の癌 抑制遺伝子の存在が予想されている(12). また実際, ヒト のグリオーマで, PEG3 遺伝子の発現が著しく低下して いる場合があることも明らかになった。これらのことか ら，筆者らはヒト PEG3 の cDNA のコーディング領域 全体をグリオーマ細胞株で強制発現させたものをヌード マウスに接種したところ, 造腫瘍性を強く阻害すること を見いだした ${ }^{(13)}$.

PEG3 のように, インプリンティングを受けている遺 伝子に癌抑制遺伝子としての働きがあった場合の特徵 は，そもそも片側の allele だけが発現しているため, Knudsonの “two-hit theory” で予想されるような, 片 側の allele の欠失ともう一方の allele の変異による機能 喪失という 2 段階のイベント ${ }^{(14)}$ は必要なく, 発現して いる側の allele のみで変異か欠失のいずれかが起きれ ば，ただちに機能袈失が起きると予想されることである (図 2).また，これに加えて最近注目されているのが, DNA メチル化などの遺伝子の不活化によって発現が失 われる機能袈失の場合でも, 実際に発現している父親由 来の allele のみの異常で癌がひき起こされることが考え られ，グリオーマの発生や悪性化に PEG3 が寄与して いる可能性については, 今後の解析が重要であろう。
A

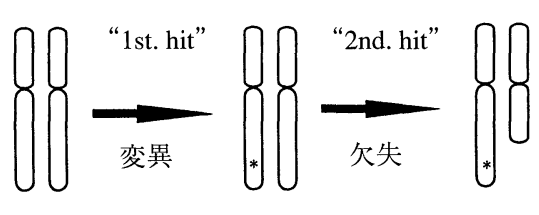

B
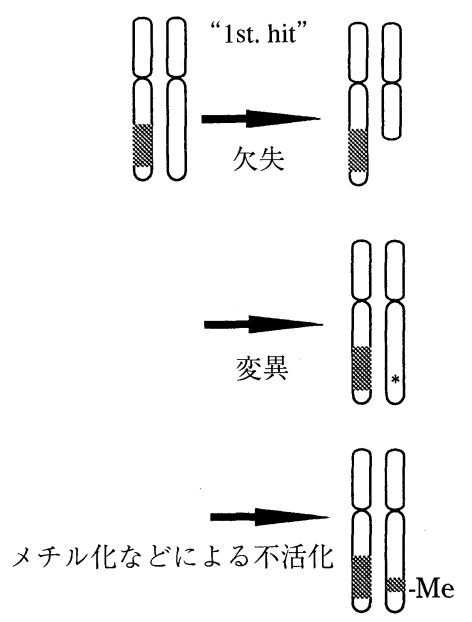

図 2 - Two-hit theory とインプリンティング

通常の遺伝子は, 雌雄両方の親に由来する染色体から等価に遺伝子が発現しているので, A に示すようにどちらか 1 つの対立遺伝子に変異 や欠失が起こっても, 残りの対立遺伝子の発現で機能が補われる。このことから Knudson は, 癌抑制遺伝子の機能が失われて発癌に至る には，両方の対立遺伝子の機能が失われる 2 つ独立した「hit」が必要であるという，“two-hit theory”を提唱した，機能峦失には，図 に示したように遺伝子の変異, 欠失などの他に, DNA メチル化の充進などによる遺伝子発現の不活化による例も知られるようになってき たが, どのような機構で不活化されるかは遺伝子によって異なっている.

しかし，インプリンティング遺伝子の場合は，B に示すように片側の対立遺伝子しか発現していないことから，1つの「hit」で機能が失わ れると考えられる. 図中*は変異による遺伝子の機能呫失を, 網かけ部はインプリンティングによって発現していない側の allele を示す. 


\section{ゲノムインプリンティングとエピジェネティク ス}

遺伝子の本体が DNA であるということが明らかにさ れる以前の 1942 年に, Waddington は, 発生に伴う遺 伝子発現制御の総体を研究する学問分野をエピジェネ ティクス (epigenetics, 後生学) と名づけた ${ }^{(15)}$.一方, 最近になって Wolffe らは，次の世代に伝わる遺伝子発 現の調節で, DNAの一次構造の変化を伴わない可逆的 な現象をエピジェネティックな現象と呼び，それを研究 する分野をエピジェネティクスと名づけることを提唱し た ${ }^{(16)}$ 。これは明らかに, 分子生物学的な立場を踏まえた 上でのジェネティクス (genetics, 遺伝学)に対応して定 義された言葉である。

Wolffe らの定義に従って考えると，多細胞生物では 発生の過程で様々なエピジェネティックな修飾が行なわ れ，これらのうちの多くは遺伝的にプログラムされたも のだと考えられるが，環境要因や偶然によって生じる可 能性も考えられる．エピジェネティックな変化は，世代 を超えるという意味では個体のレベルで考えることもで きるし, 細胞を 1 つの単位と考えれば細胞レベルでのエ ピジェネティクスを考えることもできる，それはちょう ど，一般的な遺伝学が個体レベルでの現象を考えるのに 対して, 細胞レベルでの遺伝学を考える「体細胞遺伝学」 に相当するといってもよいかもしれない. PEG3 でみら れるような，癌細胞における DNA メチル化などによる 遺伝子の不活化は，この細胞レベルでのエピジェネティ クスの例と考えられる.一方で，ゲノムインプリンティ ングは，親の世代の性に従って遺伝子のスイッチがオン になるかオフになるかが決まり，それが次世代の体細胞 ゲノムでも維持される現象であり，まさに個体レベルで のエピジェネティックな現象の典型例である. 哺乳類に おいては，エピジェネティックな修飾が次世代に受け継 がれる現象は他に知られておらず，その意味ではゲノム インプリンティングは厳密にプログラムされたエピジェ ネティックな現象として, X 染色体の不活化などととも に，そのメカニズムは示唆に富む.

\section{体細胞クローンとゲノムインプリンティング}

動物の発生過程では，1つの細胞である受精卵が分裂 を繰り返し，発生が進むに従って種々の細胞に分化して ゆく，その過程で，それぞれの細胞に特有の遺伝子発現 パターンが表われる，哺乳類においては，それぞれの細 胞の核にコードされている遺伝子の情報，すなわちゲノ ム DNA の一次構造は, 免疫細胞におけるイムノグロブ
リン遺伝子など一部の例外を除いて変化することはない と考えられてきた。しかし，細胞の分化が進むと，最初 はあらゆる細胞へと分化できる「全能性」をもっていた 細胞がその能力を失ってゆき, 遺伝子の状態が様々な修 飾によって分化した細胞の性質に固定されると考えら れ, 特に, 哺乳類のような複雑な動物では, 「全能性」を 失った体細胞からはクローン個体を作ることはできない と信じられてきた。

しかし 1997 年, Wilmut らは, それまで不可能と考え られていた哺乳類の成体体細胞からのクローン個体作製 に成功し，ヒツジの「ドリー」が誕生した ${ }^{(17)}$. その後, 続いてマウス, ウシ, ブタなどにおいても, 種々の体細 胞から核移植によってクローン動物が作製できることが 示された ${ }^{(18 \sim 20)}$. これらの体細胞クローン動物作出の成 功は, 多くの体細胞でゲノム DNA の一次構造は変化し ていないという考えを支持するとともに，発生に従って プログラムされたゲノム上の修飾は可逆的であり，未受 精卵への核移植によって，一定の条件下では「初期化」 されうることを示している．このように，クローン動物 作出の成功によって, 体細胞系列の発生に従ってプログ ラムされた DNA の修飾は, 現在一般的に使われている エピジェネティックの定義と一致することが明らかにな ったといえる.

では，体細胞クローンを作る操作で，もう一つのエピ ジェネティックな修飾であるゲノムインプリンティング は，「初期化」，あるいは何らかの影響を受けるのだろう か. Humpherys らは, 最近マウスの ES 細胞から作っ たクローン個体で，いくつかのインプリンティング遺伝 子に発現異常が認められることを報告した ${ }^{(21)}$. 一方, 筆 者らも体細胞クローン個体を用いてインプリンティング 遺伝子の発現調節を詳細に検討した。その結果, 調べた 限りすべてのインプリンティング遺伝子の片親性発現は 正常に保たれていること, 胎児での発現量についても正 常個体と違いが認められないこと, 胎盤ではインプリン ティング遺伝子を含め一部の遺伝子に発現量の異常が認 められることが明らかとなった ${ }^{(13)}$.これらの結果は, 一 見 Humpherys らの報告と矛盾するようだが, 筆者らが 解析を行なったクローン個体は, マウスの個体からとっ た体細胞を組織培養のステップをほとんど通さずに直ち に核移植したものである。それに対し, Humpherysら の実験では, 細胞株として確立した ES 細胞を核のドナ 一として用いており，それが結果が異なった原因ではな いかと考えている．実際，これまですでに Igf2やH19 といったインプリンティング遺伝子の片親性発現が ES 細胞の培養中にしばしば失われることが報告されてき 
た ${ }^{(22)}$.したがって, Humpherys ら自身も指摘している ように，これらの事実は，培養細胞をドナーとして用い る場合，元になった細胞の遺伝子発現が異常になってい ると,クローン個体でもそれをそのまま受け継いでしま う可能性があることを強く示唆している，また，見方を 変えれば，インプリンティング遺伝子のエピジェネティ ックな修飾は, 哺乳類の生活環の中で唯一生殖細胞系列 でのみ書き換えが行なわれ，体細胞クローニングのステ ップでは書き換えられることがないが, それ以外の発生 に伴って遺伝子の発現制御を行なうエピジェネティック な修飾は, クローニングにおいて発生の初期に再プログ ラム化されうることを示しているといえる.

応用面を考えれば，体細胞クローンの技術や ES 細胞 の利用は, 今後再生医療への応用や家畜の育種などで非 常に重要な技術となってゆくことは間違いない，その意 味で，インプリンティングの制御をはじめとして，エピ ジェネティックな遺伝子制御の問題は，ますます重要に なってゆくと考えられる。

$*$

1980 年代に, 受精卵の前核移植の実験によってインプ リンティングという現象が発見され，1990 年代には，体 細胞核移植によってクローン動物が作られたことによっ て，哺乳類今゙ノムのエピジェネティックな修飾について 新たな視点が拓かれつつある．細胞レベルの DNA メチ ル化やクロマチン修飾などによるエピジェネティクス， Wolffe が提唱した DNA の一次構造変化を伴わないゲ ノムの変化としてのエピジェネティクス，そして Waddington が定義した個体発生における遺伝子の発現とし てのエピジェネティクスという言葉が，クローン動物や ゲノムインプリンティングの研究を通して，大きな一つ の概念としてまとめられることを期待したい.

\section{文献}

1) M.A. Surani, S.C. Barton \& M.L. Norris : Nature, 308,
548 (1984).

2) J. McGrath \& D. Solter: Cell, 37, 179 (1984).

3) B.M. Cattanach \& M. Kirk : Nature, 315, 496 (1985).

4) R.D. Nicholls : Am. J. Med. Genet., 46, 16 (1993).

5) D. Viljoen \& R. Ramesar: J. Med. Genet., 29, 221 (1992).

6) L.D. Spotila, L. Sereda \& D.J. Prockop : Am. J. Hum. Genet., 51, 1396 (1992).

7) T.M. DeChiara, E.J. Robertson \& A. Efstratiadis : Cell, 64, 849 (1991).

8) T. Kaneko-Ishino, Y. Kuroiwa, N. Miyoshi, T. Kohda, R. Suzuki, M. Yokoyama, S. Viville, S.C. Barton, F. Ishino \& M.A. Surani : Nature Genet., 11, 52 (1995).

9) N. Miyoshi, Y. Kuroiwa, T. Kohda, H. Shitara, H. Yonekawa, T. Kawabe, H. Hasegawa, S.C. Barton, M.A. Surani, T. Kaneko-Ishino \& F. Ishino : Proc. Natl. Acad. Sci. USA, 95, 1102 (1998).

10) S. Kobayashi, H. Wagatsuma, R. Ono, H. Ichikawa, M. Yamazaki, H. Tashiro, K. Aisaka, N. Miyoshi, T. Kohda, A. Ogura, M. Ohki, T. Kaneko-Ishino \& F. Ishino : Genes Cells, 5, 1029 (2000).

11) Y. Kuroiwa, T. Kaneko-Ishino, F. Kagitani, T. Kohda, L. L. Li, M. Tada, R. Suzuki, M. Yokoyama, T. Shiroishi, S. Wakana, S.C. Barton, F. Ishino \& M.A. Surani : Nature Genet., 12, 186 (1996).

12) D.N. Louis \& J.F. Gusella : Trends Genet., 11, 412 (1995).

13) T. Kohda, A. Asai, Y. Kuroiwa, S. Kobayashi, K. Aisaka, G. Nagashima, M.C. Yoshida, Y. Kondo, N. Kagiyama, T. Kirino, T. Kaneko-Ishino \& F. Ishino: Genes Cells, 6, 237 (2001).

14) A.G. Knudson, Jr. : Mutat. Res., 247, 185 (1991).

15) C.H. Waddington : Endeavor, 1, 18 (1942).

16) A.P. Wolffe \& M.A. Matzke : Science, 286, 481 (1999).

17) I. Wilmut, A.E. Schnieke, J. McWhir, A.J. Kind \& K.H. Campbell : Nature, 385, 810 (1997).

18) T. Wakayama, A.C. Perry, M. Zuccotti, K.R. Johnson \& R. Yanagimachi : Nature, 394, 369 (1998).

19) Y. Kato, T. Tani, Y. Sotomaru, K. Kurokawa, J. Kato, H. Doguchi, H. Yasue \& Y. Tsunoda: Science, 282, 2095 (1998).

20) A. Onishi, M. Iwamoto, T. Akita, S. Mikawa, K. Takeda, T. Awata, H. Hanada \& A.C. Perry: Science, 289, 1188 (2000).

21) D. Humpherys, K. Eggan, H. Akutsu, K. Hochedlinger, W.M. Rideout, 3rd., D. Biniszkiewicz, R. Yanagimachi \& R. Jaenisch : Science, 293, 95 (2001).

22) W. Dean, L. Bowden, A. Aitchison, J. Klose, T. Moore, J. J. Meneses, W. Reik \& R. Feil : Development, 125, 2273 (1998).

お知らせ

日時：平成 14 年 7 月 16 日 (火) 18 日 (木)

会場：つくば国際会議場（つくば市竹園 2-20-3）

主催：日本 RNA 学会

参加費：学会員…一般：13,000 円, 学生 : 5,000 円

非学会員…一般：18,000 円, 学生：7,000円

参加申込：E-mail にて受付. 7 月 5 日 (金) 締切

世話人：多比良和誠

\section{日本 RNA 学会年会}

第 4 回 $\mathrm{RNA}$ ミーティング

事務局：干 113-8656 東京都文京区本郷 7-3-1

東京大学大学院工学系研究科 化学生命工学専攻

多比良研究室内（担当）東 牧子

Tel \& Fax : 03-5841-7340

E-mail : rna2002@chembio.t.u-tokyo.ac.jp

http://www.chem.t.u-tokyo.ac.jp/chembio/labs/taira/ rna2002/ 